\title{
Relative influence of direct and indirect environmental effects on sestonic chlorophyll-a concentration in Cerrado streams
}

\author{
Influência relativa de efeitos ambientais diretos e indiretos na concentração da \\ clorofila-a planctônica em riachos do Cerrado
}

\author{
Pedro Paulino Borges ${ }^{1}$, Fabrício Barreto Teresa ${ }^{1}$, Patrick Thomaz de Aquino Martins ${ }^{1}$ \\ and João Carlos Nabout ${ }^{1}$
${ }^{1}$ Universidade Estadual de Goiás - UEG, Câmpus de Ciências Exatas e Tecnológicas CCET, BR 153, 3105, CEP 75132-903, Anápolis, GO, Brazil
e-mail: pedropaulinoborges_@hotmail.com; fabricioteresa@yahoo.com.br; patrick_thomaz@yahoo.com.br; joao.nabout@ueg.br

\begin{abstract}
Aim: Chlorophyll- $a$ may be directly influenced by local variables and/or indirectly by land use and cover, once landscape modifications change limnological variables, which in turn affect the primary productivity of aquatic environments, e.g., streams. Therefore, the objective of this study was to determine the relative importance of the local and landscape environmental components and assess the direct and indirect effects of these variables on sestonic chlorophyll- $a$ concentration in 30 Cerrado streams (Santa Teresa River basin). Results: All aquatic environments were oligotrophic during the study period. Only the local variables were important to explain chlorophyll- $a$ variation $\left(\mathrm{R}^{2}=0.27 ; P=0.04\right)$. In addition, the path analysis showed that all variables used in the analysis influenced chlorophyll- $a$ concentration more directly than indirectly. Conductivity was the most important variable to directly influence chlorophyll- $a$, followed by turbidity. Conclusion: The large amount of remnant native vegetation in the basin indicates that the region studied is well preserved, which may explain the greater importance of local variables and the low effect of the landscape in explaining chlorophyll- $a$ variation.
\end{abstract}

Keywords: phytoplankton; conductivity; variation partitioning; landscape ecology; stream ecology.

Resumo: Objetivo: A clorofila- $a$ pode ser influenciada diretamente por variáveis locais e/ou indiretamente pelo cobertura e uso do solo, uma vez que alteraçóes na paisagem promovem mudanças em variáveis limnológicas, o que por sua vez afeta a produtividade primária de ambientes aquáticos tais como riachos. Portanto, o objetivo deste trabalho foi determinar a importância relativa dos componentes ambientais locais e de paisagem e verificar os efeitos diretos e indiretos dessas variáveis na concentração da clorofila- $a$ planctônica em 30 riachos do Cerrado (Bacia do rio Santa Teresa). Resultados: Os ambientes aquáticos durante o período de estudo foram oligotróficos. Somente as variáveis locais foram importantes para explicar a variaçâo da clorofila- $a$ $\left(\mathrm{R}^{2}=0,27 ; P=0,04\right)$. Além disso, a análise de caminhos demonstrou que todas as variáveis utilizadas na análise influenciaram mais de forma direta do que indiretamente a concentração de clorofila- $a$. Diretamente a condutividade foi a variável mais importante, seguida de turbidez. Conclusóes: A grande proporção de vegetação nativa remanescente na bacia indica que a região de estudo ainda é bastante preservada, o que pode explicar a maior importância das variáveis locais em detrimento do pequeno efeito da paisagem na variaçáo da clorofila- $a$.

Palavras-chave: fitoplâncton; condutividade; partiçấo da variância; ecologia de paisagem; ecologia de riachos. 


\section{Introduction}

Chlorophyll- $a$ is a photosynthetic pigment found in all organisms that perform photosynthesis. The sestonic chlorophyll- $a$, represented by phytoplankton, are photosynthetic organisms that comprise eukaryotic organisms as well as cyanobacteria (Lee, 2008; Kilroy et al., 2013). These organisms are good indicators of environmental quality for being sensible to environmental changes and having a fast response, due to their short lifespan (Lee, 2008). Chlorophyll- $a$ has been continuously studied (Marcionilio et al., 2015) and is a good representative of phytoplankton biomass (Boyer et al., 2009; Carneiro et al., 2014) and may be used to indicate environmental degradation (Figueroa-Nieves et al., 2006; Boyer et al., 2009; Carneiro et al., 2014) in freshwater environments, e.g., streams (Dodds et al., 1998).

Chlorophyll- $a$ concentration is influenced by several factors acting directly and/or indirectly (Urrea-Clos et al., 2014; Miranda et al., 2014; Carneiro et al., 2014). Local environmental factors, such as limnological variables (e.g., nutrients, transparency, among others), structure of riparian vegetation, and aquatic herbivores are the main factors to directly determine chlorophyll-a (Carneiro et al., 2014). On the other hand, these local variables may be affected by environmental landscape characteristics (e.g., land use and cover), indicating an indirect effect of the landscape variables on chlorophyll- $a$ concentration (Miranda et al., 2014; Urrea-Clos et al., 2014).

The land cover conversion (to agriculture or livestock) and consequent loss of native vegetation leads to an increase in the input of sediment into the aquatic environment during rainy periods. Such increase in sediment input causes an increase in total solids and turbidity in aquatic ecosystems (Liu et al., 2008; Izagirre et al., 2009). Moreover, when soil without natural vegetation are near agricultural areas, fertilizers, may be carried to the aquatic environment and cause an oversupply of nutrients. These changes result in the increase of chlorophyll- $a$ concentrations, showing the indirect influence of land use and cover, via nutrients, on chlorophyll- $a$ concentration (Urrea-Clos et al., 2014; Miranda et al., 2014).

The connection between terrestrial and aquatic ecosystems and how aquatic environments respond to peripheral influences is a major paradigm within aquatic ecology (Ward, 1998). Cerrado (Brazilian Savanna) aquatic environments may be used as models to test the influence of direct and indirect effects on primary productivity, especially given that the Cerrado has experienced strong changes in natural landscapes, converting natural vegetation to agropastoral environments (Klink \& Machado, 2005). Therefore, considering that the aquatic environments are directly and indirectly affected by characteristics of the surrounding terrestrial ecosystems, the objective of this study was to determine the relative importance of the local and landscape environmental components and verify if the direct and indirect effects of these variables on sestonic chlorophyll-a concentrations in Cerrado streams. The hypotheses of the present study were: i) Most of the variation of chlorophyll-a should be explained by local components; ii) The effects of the landscape should be important indirectly affecting the chlorophyll-a.

\section{Material and Methods}

\subsection{Study area}

Samples were collected in Cerrado areas, within the Santa Teresa River basin in the north of Goiás State between the months of August and September 2013 (dry season). A total of 30 streams were sampled (Figure 1). The Santa Teresa River basin is inserted in the Upper Tocantins River System, macro-regional context of the Tocantins - Araguaia basin region. The streams of Santa Teresa presented interspersed areas with rapids waters, corridors and backwaters, and with substrates composed of silt, sand, gravel, pebbles, boulders and rocks. The marginal vegetation consists of grasses, shrubs and trees. The climate is humid tropical type, highlighting two well defined seasons, with the rainy season during the months from October to April and the dry season from May to September. The average annual temperature in the region is between 21 to $25^{\circ} \mathrm{C}$.

\subsection{Data sampling}

\subsubsection{Chlorophyll-a}

A habitat with higher amounts of standing water was selected and five liter samples of water were obtained in each sampling site to obtain the chlorophyll- $a$. Then, samples were filtered in Whatman glass fiber disks, GF/C with $47 \mathrm{~mm}$ diameter and pore of $0.45 \mu \mathrm{m}$. The largest possible amount of water was filtered. The filter was stored in aluminum foil after filtering, stored in the dark and was kept frozen in the refrigerator until sample processing (APHA, 1995). We used the Golterman et al. (1978) methodology to analyze the Chlorophyll-a 


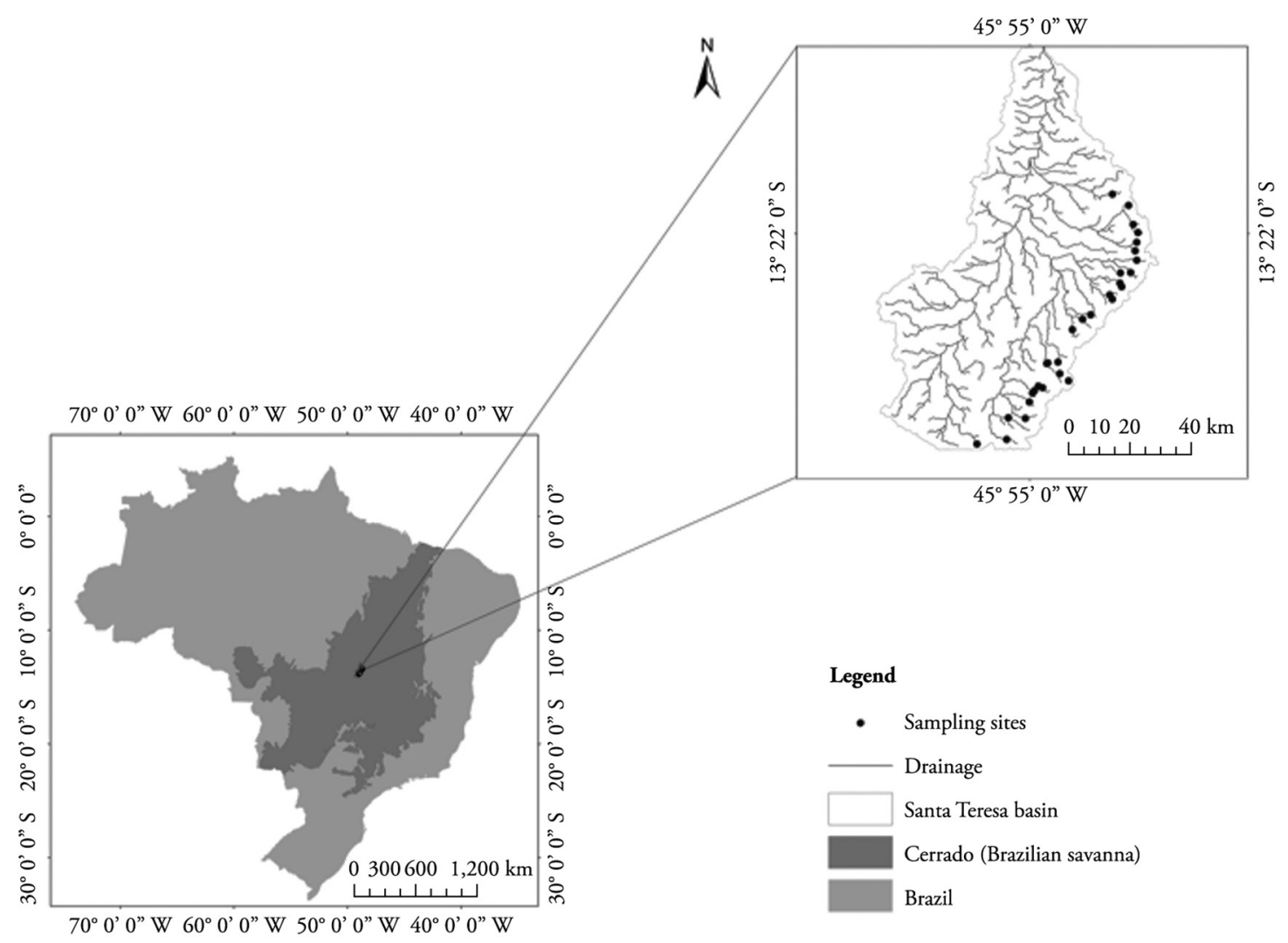

Figure 1. Location of the study area in Brazil.

\subsubsection{Local variables}

The following variables were measured in each stream, at the site where the water sample for Chlorophyll- $a$ was obtained: $\mathrm{pH}$ (hydrogenionic potential), conductivity, dissolved oxygen, water temperature, total dissolved solids and turbidity. All of the aforementioned variables were obtained in the field using Digimed sensors. In addition, $500 \mathrm{~mL}$ water samples were collected and stored in polyethylene bottles for total nitrogen and total phosphorus analysis. These polyethylene bottles were transported in a Styrofoam box with ice, and frozen for later analysis in lab (APHA, 1995). The water flow was also obtained for each site with a flowmeter (Mechanical flowmeters, model 2030 series).

The morphometric variables were width and depth, obtained through field measurements. Width was calculated using a tape measure, and depth using a depth gauge. In addition, forest cover pictures were taken in each stream to verify the percentage of shading. Then, these pictures were classified under supervision using the maximum likelihood method in the software ENVI 4.7. After classification of the data we obtained the shading for each streams.

\subsubsection{Landscape variables}

The landscape variables used in this study were land use and micro-basin area variables, and were obtained by geoprocessing in the micro-basins upstream to the sampling sites. Rapideye satelite images with a $5 \mathrm{~m}$ spatial resolution were used. Satelite images were obtained for free thorough the Ministério do Meio Ambiente (BRASIL, 2014).

The images used (referring to 2011, 2012 and 2013) were already orthorectified, therefore, dismissing the need of performing geometric correction (georeferencing). The drainage was obtained through the digital processing of SRTM (Shuttle Radar Topography Mission) images, obtained from the website of the Ministério da Agricultura, Pecuária e Abastecimento (Miranda, 2005). The area of the micro-basin upstream to each sampling site was obtained from a point vector file inserted in the drainage network for each site. The area of the micro-basin was later used like mask to make the cropping on high-resolution images.

After cropping, contrast was applied and the segmentation was carried out in the RapidEye images, using a $95 \%$ similarity threshold and an area referring to 60 pixels. A supervised classification 
was carried out after segmentation using the Bhattacharya distance (Bins et al., 1996), with a 95\% similarity threshold. The landscape classes used were remnant, pasture, exposed soil, water and urban area. The wrongly classified polygons were edited after the classification. Then, the data of each land use and soil coverage class (in $\mathrm{km}^{2}$ ) were obtained.

\subsection{Data analysis}

The relative importance of local and landscape components on chlorophyll-a concentration was investigated through a partial multiple regression. This analysis comprises four unique components that explain the variation in chlorophyll-a concentration throughout the gradient sampled: [a] variation explained only by local environmental factors; [b] local and landscape variation; [c] variation explained only by landscape factors; [d] residual variation (Legendre \& Legendre, 1998). The variables used in the partial multiple regression were chlorophyll-a (response variable) and the local and landscape variables (both predictors). The non-collinear local environmental variables were selected using the Principal Component Analysis (PCA; Figure 2, Table 1). Thus, the following non-collinear local variables were used in the regression: conductivity, width, temperature, $\mathrm{pH}$, turbidity and shading. The landscape variables were represented by Cerrado remnant and sub-basin area. The occurrence of spatial autocorrelation in residual of the regression was tested after the analysis to assess the inflation of Type I error (Legendre \& Legendre, 1998). We constructed the spatial correlogram of Moran I with five distances classes. High Moran I in first distance class indicate spatial autocorrelation and inflation of Type I error. The function varpart, package vegan (Oksanen et al.,

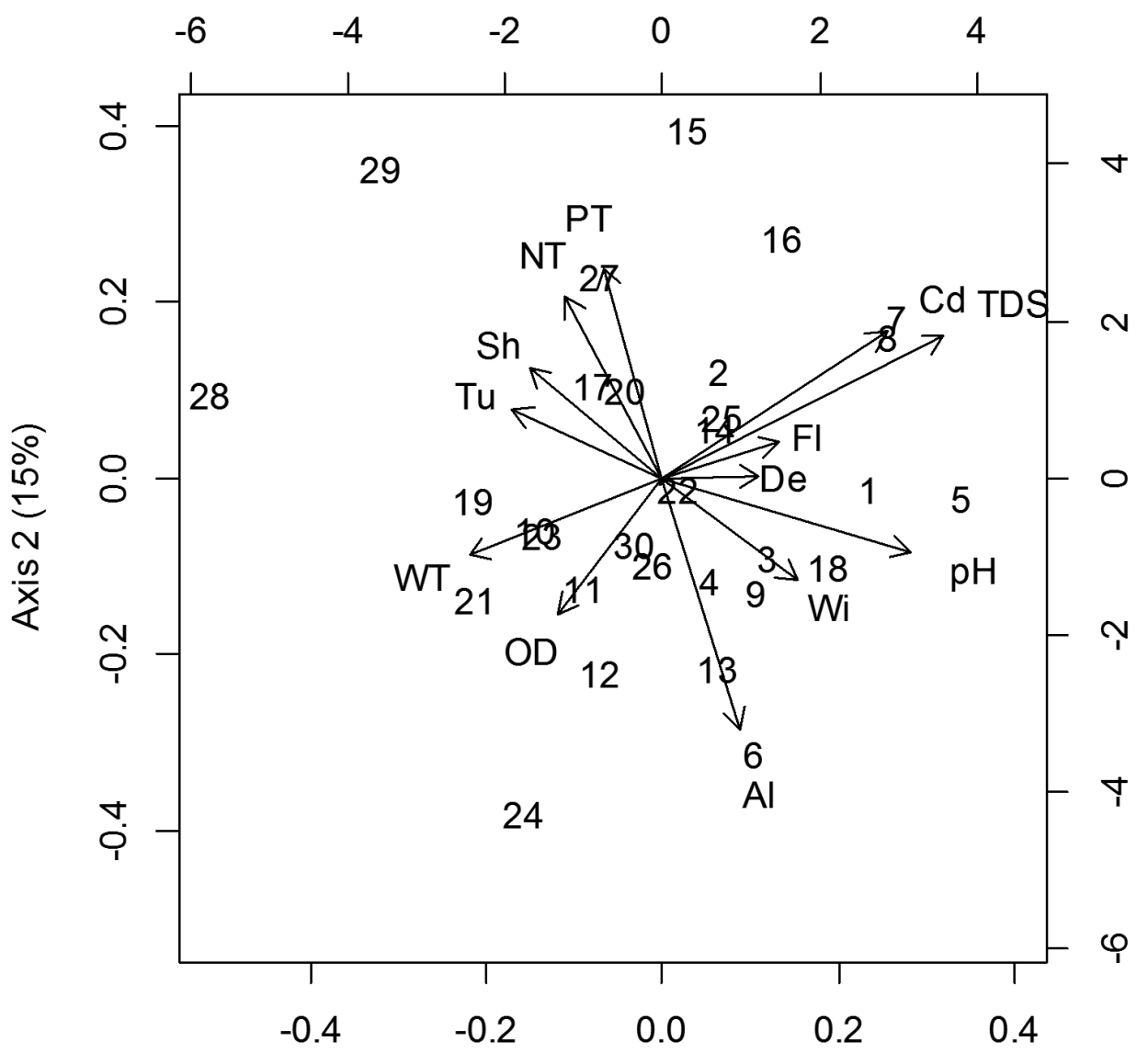

Axis $1(22 \%)$

Figure 2. Principal Component Analysis (PCA) of environmental variables streams analyzed. PT - Total Phosphorus, NT - Total Nitrogen, CD - Conductivity, OD - Dissolved Oxygen, pH - Hydrogenionic Potential, WT - Water Temperature, Tu - Turbidity, TDS - Total Dissolved Solids, De - Depth, Fl - Flow, Sh - Shading, Wi - Width, Al - Altitude. 
2013) of the software R (R Core Development Team, 2015) was used for these analyses.

A path analysis (Legendre \& Legendre, 1998) was carried out to assess the direct and indirect effects of local and landscape variables on chlorophyll-a concentration. The path analysis was carried out following a consensual model where local variables directly affect chlorophyll- $a$ and the landscape variable indirectly affects chlorophyll-a concentrations. The local environmental variables selected by the PCA (conductivity, width, temperature, $\mathrm{pH}$, turbidity and shading) and the landscape variable (remnant Cerrado vegetation) were the predictor variables in the proposed model,

Table 1. Loading matrix of all variables on each principal component (PC). See legends in Figure 2.

\begin{tabular}{crc}
\hline & PC1 & PC2 \\
\hline PT & -0.101 & 0.428 \\
NT & -0.166 & 0.370 \\
CD & 0.384 & 0.299 \\
OD & -0.177 & -0.278 \\
pH & 0.425 & -0.150 \\
WT & -0.332 & -0.159 \\
Tu & -0.258 & 0.140 \\
TDS & 0.483 & 0.289 \\
De & 0.166 & 0.004 \\
FI & 0.199 & 0.071 \\
Sh & -0.227 & 0.222 \\
Wi & 0.230 & -0.207 \\
Al & 0.132 & -0.513 \\
\hline
\end{tabular}

while the response variable was chlorophyll- $a$ concentration. For this analysis we used the function path.analysis, package Agricolae (Mendiburu, 2014) of software R (R Core Development Team, 2015). The limnological, morphometric and chlorophyll- $a$ data used in the analyses were standardized using $\mathrm{Z}$ scores and the landscape data were standardized using the arcsine of the square root.

\section{Results}

The average chlorophyll-a concentration in streams was low $(1.37 \mu \mathrm{g} / \mathrm{l})$. The highest concentration $(2.95 \mu \mathrm{g} / \mathrm{l})$ was recorded in stream 19 and lowest $(0.30 \mu \mathrm{g} / \mathrm{l})$ in stream seven (see Table 2 for descriptive statistics). The average total nitrogen and total phosphorus values were also low. The streams had a low water flow, a $\mathrm{pH}$ level near neutrality, were shallow, transparent and had a high average of shading.

The Cerrado remnants prevailed in most of the studied area, followed by pasture (Figure 3). There was a low prevalence of exposed soil, urban area and water. In addition, no agricultural areas were detected in the analyzed sub-basins.

The local and landscape components, jointly, explained $44 \%$ of the chlorophyll- $a$ variation within streams. However, individually, only the local environmental components significantly explain the variation in chlorophyll- $a$ concentrations (Table 3). The regression residual was not

Table 2. Statistical descriptors of local and landscape variables measured in the studied streams.

\begin{tabular}{|c|c|c|c|c|}
\hline Local variables & Average & Minimum & Maximum & $\begin{array}{l}\text { Coefficient of } \\
\text { variation (\%) }\end{array}$ \\
\hline Altitude (m) & 482.17 & 403 & 559 & 8.21 \\
\hline Chlorophyll-a ( $\mu \mathrm{g} / \mathrm{l})$ & 1.37 & 0.30 & 2.95 & 45.21 \\
\hline Conductivity ( $\mu \mathrm{s} / \mathrm{cm})$ & 147.58 & 45.5 & 343 & 51.43 \\
\hline Flow $(\mathrm{m} / \mathrm{s})$ & 36.77 & 0 & 398 & 217.05 \\
\hline Total phosphorus (ug/L) & 5.23 & 0.70 & 15.27 & 85.68 \\
\hline Width (m) & 3.15 & 1.44 & 6.08 & 37.92 \\
\hline Total nitrogen (ug/L) & 0.41 & 0.12 & 0.70 & 31.77 \\
\hline Dissolved oxygen (mg/l) & 5.84 & 4.06 & 7.35 & 16.68 \\
\hline $\mathrm{pH}$ & 6.85 & 5.05 & 8.01 & 10.39 \\
\hline Total dissolved solids (mg/l) & 259.94 & 192.1 & 298 & 10.10 \\
\hline Shading (\%) & 62.61 & 22.58 & 95.48 & 36.50 \\
\hline Water temperature $\left({ }^{\circ} \mathrm{C}\right)$ & 25.97 & 22 & 29.2 & 8.56 \\
\hline Depth (cm) & 16.02 & 7.41 & 31.87 & 38.11 \\
\hline Turbidity (NTU) & 28.40 & 10.9 & 88.7 & 76.58 \\
\hline \multicolumn{5}{|l|}{ Landscape variables } \\
\hline Pasture (\%) & 18.59 & 0.39 & 57.77 & 73.87 \\
\hline Remnant (\%) & 81.16 & 41.81 & 99.45 & 17.03 \\
\hline Water (\%) & 0.02 & 0 & 0.26 & 2.32 \\
\hline Exposed soil (\%) & 0.20 & 0 & 1.31 & 1.37 \\
\hline Urban area (\%) & 0.01 & 0 & 0.41 & 5.17 \\
\hline Basin area $\left(\mathrm{Km}^{2}\right)$ & 16.39 & 0.13 & 49.56 & 76.50 \\
\hline
\end{tabular}




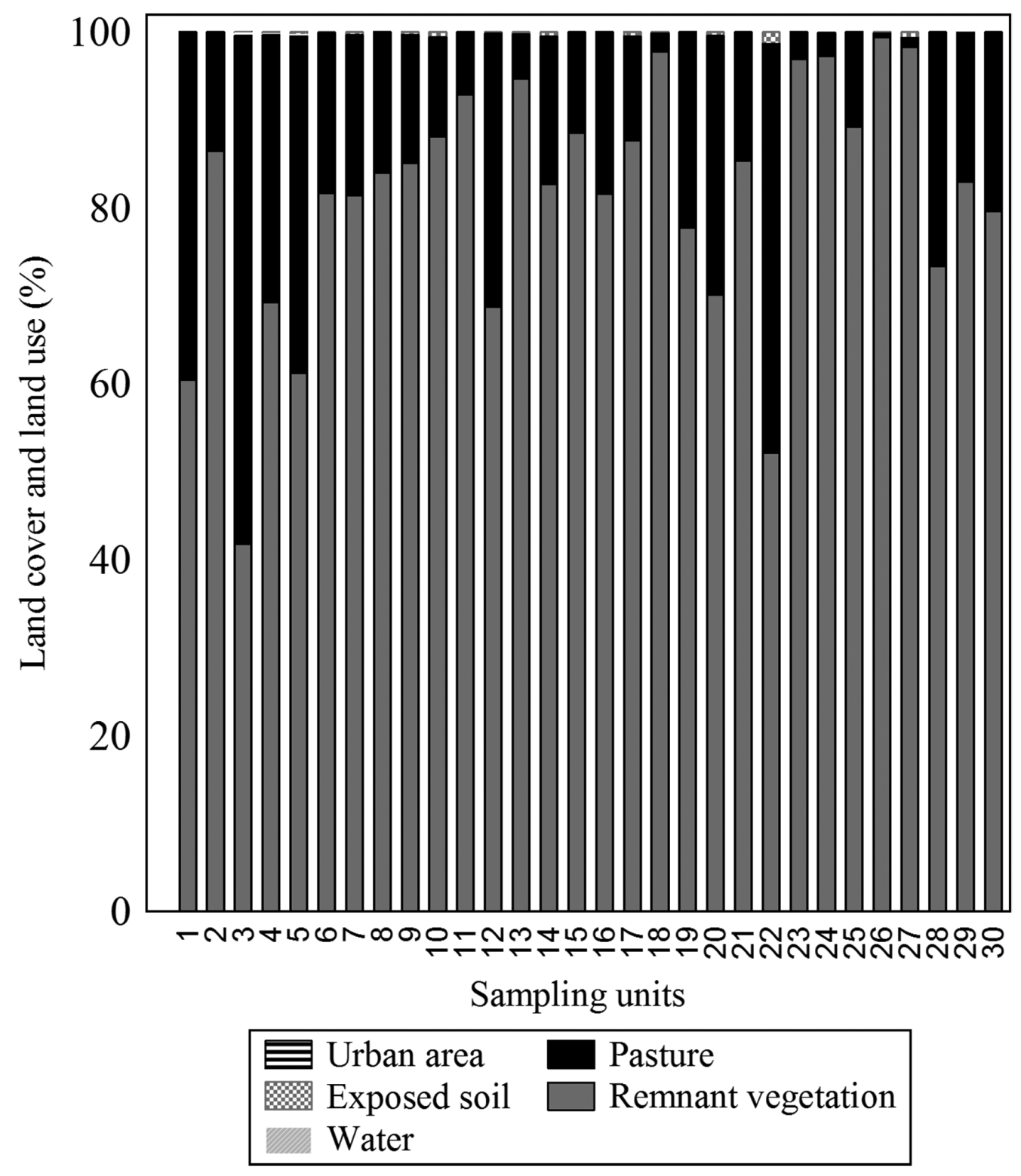

Figure 3. Land use and cover class in the 30 sub-basins upstream of the collection points.

Table 3. Individual importance of the local and landscape components in determining chlorophyll- $a$ concentration.

\begin{tabular}{lcc}
\hline \multicolumn{1}{c}{ Components } & $\mathbf{R}^{\mathbf{2}} \mathbf{a d j}$ & $\boldsymbol{P}$ \\
\hline (a) Local & 0.27 & $\mathbf{0 . 0 4}$ \\
(b) Shared & -0.04 & \\
(c) Landscape & 0.003 & 0.36 \\
(d) Residual & 0.77 & \\
\hline
\end{tabular}

Values in bold indicate $\mathrm{P}<0.05$. (a) variation explained only by local environmental factors; (b) local and landscape variation; (c) variation explained only by landscape factors; (d) residual variation.

spatially autocorrelated (Moran's I in first distance class $=-0.06 ; P=0.55)$.

The most important local variable, and only to significantly explain the variation in chlorophyll-a concentrations was conductivity $\left(\mathrm{R}^{2}=0.16\right.$; $P=0.02$; Table 4). Conductivity was negatively related to chlorophyll- $a$.

All variables used in the path analysis (local and landscape variables) had more direct than indirect influence in the concentration of chlorophyll-a (Figure 4). In addition, conductivity and turbidity were the only variables to be significantly related $(\mathrm{P}<0.05)$ with chlorophyll- $a$ (in a direct effect).

\section{Discussion}

The streams of Santa Teresa river presented low chlorophyll- $a$ concentration, low nutrient concentration and high transparency. Theses limnological features indicate that study area is 


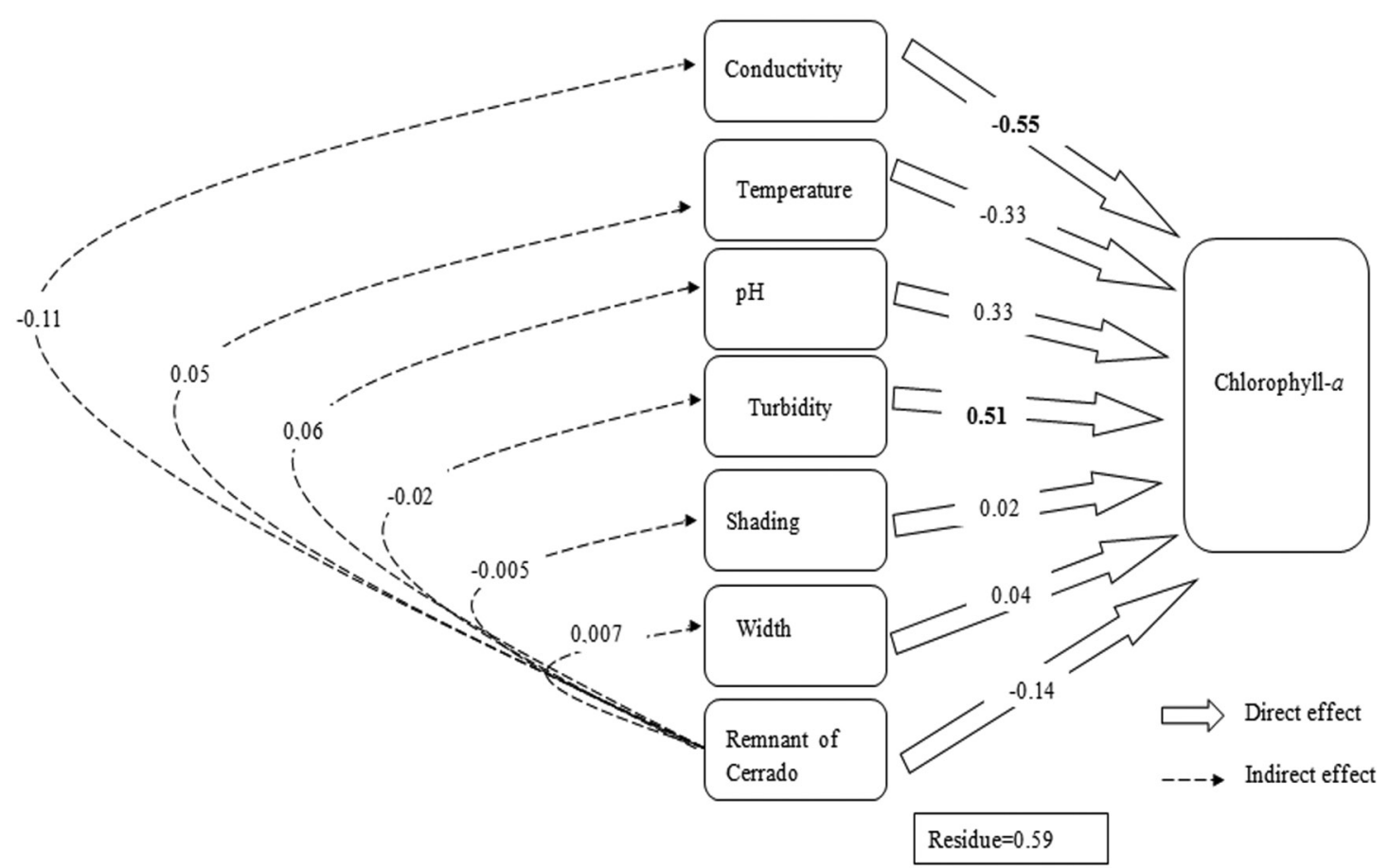

Figure 4. Path diagram, showing the direct and indirect effects of local and landscape variables on chlorophyll- $a$ concentration. Values in bold indicate $\mathrm{P}<0.05$.

Table 4. Isolated importance of the local environmental components $\left(\mathrm{R}^{2} \mathrm{adj}\right)$ and slope of the relationship of the local environmental variable with chlorophyll-a concentration.

\begin{tabular}{lrlr}
\hline \multicolumn{1}{c}{ Variables } & $\mathbf{R}^{2}$ adj & $\boldsymbol{P}$ & $\begin{array}{c}\text { Angular } \\
\text { coefficient }\end{array}$ \\
\hline pH & 0.05 & 0.13 & 0.292295 \\
Conductivity & 0.16 & $\mathbf{0 . 0 2}$ & -0.005935 \\
Width & -0.03 & 0.7 & -0.112952 \\
Temperature & 0.04 & 0.14 & -0.099453 \\
Turbidity & 0.05 & 0.12 & 0.012177 \\
Shading & -0.02 & 0.60 & 0.000379 \\
\hline
\end{tabular}

Values in bold indicate $\mathrm{P}<0.05$.

oligotrophic (Dodds et al., 1998). Other studies in streams that also investigated sestonic chlorophyll-a, found lowest values (and similar to this paper $\left.<5 \mu \mathrm{gL}^{-1}\right)$ in more pristine environments and a higher percentage of vegetation (Choi et al., 2015; Dodds et al., 1998). In addition, this study investigated the sestonic chlorophyll- $a$, which is less than the benthic chlorophyll-a. However, both are positively related, mainly because considerable part of the planktonic community comes from the bentonic community (Swanson $\&$ Bachmann, 1976). Therefore, in a space research (such as the present paper), areas with the highest concentration of benthic chlorophyll-a must also possess higher sestonic chlorophyll- $a$.
We found that local environmental factors are the main factors to determine chlorophyll-a variation using different methodological approaches (multiple regression and path analysis). In addition, the indirect effects of land cover had little effect on phytoplankton. Recent studies have highlighted the importance of local environmental components in structure of aquatic communities, such as algae (Algarte et al., 2014; Huszar et al., 2015), fish (Beisner et al., 2006) and chlorophyll-a (Carneiro et al., 2014). Moreover, the importance of local and landscape components has been investigated in aquatic environments with different impacts. For example, Choi et al. (2015) investigated sestonic chlorophyll- $a$ in 70 Korean streams with different land uses and cover (forest and urban); they found that land use and total phosphorus were more important in explaining the variation of chlorophyll-a. However, few studies have quantitatively investigated the indirect effects of the landscape on aquatic environments (e.g., Miranda et al., 2014).

Landscape characteristics are conceptually expected to affect indirectly in chlorophyll-a concentration. However, the level of interference also depends on local factors, such as depth, width and characteristics of the surrounding environment (Miranda et al., 2014). For example, the presence of riparian vegetation in the sample points (shading 
as proxy) can tamponate the negative influence of landscape on the local conditions (Náiman \& Décamps, 1997). Therefore, the low influence of the landscape variables on chlorophyll- $a$ (reflected in a low explanatory power) reported in this study is due to the condition of the sub-basins, which mostly show a high percentage of remnant vegetation. In addition, the dry period may also have contributed towards this result, once there is little runoff of the components accumulated in the basin (e.g. nutrients) to the aquatic ecosystem during this period (Ferrareze, 2012).

The importance of conductivity and turbidity is highlighted among the local variables. The increase in conductivity may affect physiological processes of the phytoplankton, hindering the development of new cells or even diminishing photosynthesis (Silva et al., 2000). Such effect of conductivity may explain the negative relationship between chlorophyll- $a$ and conductivity found in this study. Standing water environments usually occur during the dry period due to low river flow; moreover, in this study the samples occurred during the dry season and due of low river flow, the sampled habitats may be similar to lentic environments. Nonetheless, the material present at the bottom of the streams may be resuspended, causing a decrease in primary productivity with increased conductivity (Boyer et al., 2009). Resuspension may occur through water flow changes or even through the wind (Esteves \& Suzuki, 2011) and species such as fish and other organisms that revolve the stream bottom seeking for food (Maurer et al., 2014). Moreover, more turbid environments are expected to have lower primary productivity (Liu et al., 2008; Izagirre et al., 2009). Nonetheless, in regions with low concentration of chlorophyll-a, few local environmental modifications (e.g. resuspension of sediments) could increase the availability of nutrients which would result in increased concentration of chlorophyll-a. In addition, other studies have showed dominance of species of cyanobacteria and increasing blooms in more turbid and slow environments (see Scheffer et al., 1997). Therefore, the relationship of turbidity with the chlorophyll- $a$ or other aspects of phytoplankton community (e.g. species richness and biovolume) are not clear and monotonic. Factors such as species composition and local environmental conditions also affect this relationship.

Finally, this study showed that chlorophyll-a in headwater streams is, relatively speaking, more influenced by local environmental variables and that indirect landscape variables have less effect. With that, landscape variables may not be said to not affect aquatic environments, once there are clear evidences of the interaction between aquatic and terrestrial environments (see Ward, 1998; Miranda, 2005; Urrea-Clos et al., 2014). For this study, the presence of riparian vegetation may have neutralized the landscape influences in the sampled streams. We highlight that studies aggregating landscape variables, local environmental variables and information on hydrodynamics are critical to understand the factors that affect phytoplankton in streams.

\section{Acknowledgements}

We would like to thank anonymous reviewer for their helpful comments on the manuscript. We thank the National Council for Scientific and Technological Development (Conselho Nacional de Desenvolvimento Científico e Tecnológico - CNPq; process 473730/2013-8), CAPES (2036/2013) and FAPEG (process 201210267001071) for the finantial support. PPB thanks the Higher Education Personnel Improvement Coordination (Coordenação de Aperfeiçoamento de Pessoal de Nivel Superior-CAPES) for the master's scholarship. We also thank the Ministry of the Environment (Ministério do Meio Ambiente - MMA) for the high-resolution satellite images. PTAM and FBT thank UEG for the research grant PROBIP/UEG. JCN thanks CNPq (process 309700/2013-2) for the Research Productivity Scholarship.

\section{References}

ALGARTE, V.M., RODRIGUES, L., LANDEIRO, V.L., SIQUEIRA, T. and BINI, L.M. Variance partitioning of deconstructed periphyton communities: does the use of biological traits matter? Hydrobiologia, 2014, 722(1), 279-290. http://dx.doi. org/10.1007/s10750-013-1711-6.

AMERICAN PUBLIC HEALTH ASSOCIATION APHA. Standard methods for the examination of water and wastewater. Washington: APHA, 1995, $1600 \mathrm{p}$.

BEISNER, B.E., PERES-NETO, P.R., LINDSTROM, E.S., BARNETT, A. and LONGHI, M.L. The role of environmental and spatial processes in structuring lake communities from bacteria to fish. Ecology, 2006, 87(12), 2985-2991. http://dx.doi. org/10.1890/0012-9658(2006)87[2985:TROEAS] 2.0.CO;2. PMid:17249222.

BINS, L.S., FONSECA, L.M.G., ERTHAL, G.J. and II, F.A.M. Satellite imagery segmentation: a region growing approach. In Proceedings of VIII Brazilian 
Remote Sensing Symposium. Salvador: National Institute for Space Research, 1996, pp. 677-680.

BOYER, J.N., KELBLE, C.R., ORTNER, P.B. and RUDNICK, D.T. Phytoplankton bloom status: Chlorophyll a biomass as an indicator of water quality condition in the southern estuaries of Florida, USA. Ecological Indicators, 2009, 98(6), 56-67. http:// dx.doi.org/10.1016/j.ecolind.2008.11.013.

BRASIL. Ministério do Meio Ambiente. Geo catálogo $M M A$ [online]. Brasília: MMA, 2014 [viewed 26 June 2014]. Available from: http://www.geocatalogomma. com.br/faq.jhtml\#load $=8$

CARNEIRO, F.M., NABOUT, J.C., VIEIRA, L.C.G., ROLAND, F. and BINI, L.M. Determinants of chlorophyll- $a$ concentration in tropical reservoirs. Hydrobiologia, 2014, 740(1), 89-99. http://dx.doi. org/10.1007/s10750-014-1940-3.

CHOI, J.W., HAN, J.H., PARK, C.S., KO, D.G., KANG, H.I., KIM, J.Y., YUN, Y.-J., KWON, H.-H. and AN, K.-G. Nutrients and sestonic chlorophyll dynamics in Asian lotic ecosystems and ecological stream health in relation to land-use patterns and water chemistry. Ecological Engineering, 2015, 79, 15-31. http://dx.doi.org/10.1016/j. ecoleng.2015.03.006.

DODDS, W.K., JONES, J.R. and WELCH, E.B. Suggested classification of stream trophic state: distributions of temperate stream types by chlorophyll, total nitrogen, and phosphorus. Water Research, 1998, 32(5), 1455-1462. http://dx.doi. org/10.1016/S0043-1354(97)00370-9.

ESTEVES, F.A. and SUZUKI, M.S. Comunidade fitoplanctônica. In F.A. ESTEVES, org. Fundamentos de limnologia. 3rd ed. Rio de Janeiro: Editora Interciência, 2011, pp. 276-445.

FERRAREZE, M. The effect of the land use on phytoplankton assemblages of a Cerrado stream (Brazil). Acta Limnologica Brasiliensia, 2012, 24(1), 43-51. http://dx.doi.org/10.1590/S2179975X2012005000025.

FIGUEROA-NIEVES, D., ROYER, T.V. and DAVID, M.B. Controls on chlorophyll- $a$ in nutrient-rich agricultural streams in Illinois, USA. Hydrobiologia, 2006, 568(1), 287-298. http://dx.doi.org/10.1007/ s10750-006-0114-3.

GOLTERMAN, H.L., CLYMO, R.S. and OHMSTAD, M.A.M. Methods for physical and chemical analysis of freshwaters. Oxford: Blackwell Scientific Publication, 1978.

HUSZAR, V.L.M., NABOUT, J.C., APPEL, M., SANTOS, J., ABE, D.S. and SILVA, L.H.S. Environmental and not spatial processes (directional and non-directional) shape the phytoplankton composition and functional groups in a large subtropical river basin. Journal of Plankton Research,
2015 [ahead of print]. http://dx.doi.org/10.1093/ plankt/fbv084.

IZAGIRRE, O., SERRA, A., GUASCH, H. and ELOSEGI, A. Effects of sediment deposition on periphytic biomass, photosynthetic activity and algal community structure. The Science of the Total Environment, 2009, 407(21), 5694-5700. http://dx.doi.org/10.1016/j.scitotenv.2009.06.049. PMid:19666189.

KILROY, C., BOOKER, D.J., DRUMMOND, L., WECH, J.A. and SNELDER, T.H. Estimating periphyton standing crop in streams: a comparison of chlorophyll a sampling and visual assessments. New Zealand Journal of Marine and Freshwater Research, 2013, 47(2), 208-224. http://dx.doi.org/10.1080/0 0288330.2013 .772526 .

KLINK, C.A. and MACHADO, R.B. Conservation of the Brazilian cerrado. Conservation Biology, 2005, 19(3), 707-713. http://dx.doi.org/10.1111/j.15231739.2005.00702.x.

LEE, R.E. Phycology. Cambridge: Cambridge University Press, 2008, 547 p.

LEGENDRE, P. and LEGENDRE, L. Numerical ecology. Amsterdam: Elsevier, 1998, 853 p.

LIU, X., ZHANG, X. and ZHANG, M. Major factors influencing the efficacy of vegetated buffers on sediment trapping: A review and analysis. Journal of Environmental Quality, 2008, 37(5), 16671674. http://dx.doi.org/10.2134/jeq2007.0437. PMid:18689727.

MARCIONILIO, S.M.L.O., ALVES, M.T.R., BORGES, P.P., MACHADO, K.B., ARAUJO, C.S.T., CUNHA, H.F. and NABOUT, J.C. The state of global scientific literature on chlorophyll- $A$. Bioscience Journal, 2015, 31(3), 941-950. http:// dx.doi.org/10.14393/BJ-v31n3a2015-23585.

MAURER, K.M., STEWART, T.W. and LORENZ, F.O. Direct and indirect effects of fish on invertebrates and tiger salamanders in prairie pothole wetlands. Wetlands, 2014, 34(4), 735-745. http://dx.doi. org/10.1007/s13157-014-0538-x.

MENDIBURU, F. Statistical procedures for agricultural research: package 'agricolae' [online]. CRAN, 2014 [viewed 10 Nov. 2014]. Available from: http://cran.rproject.org/web/packages/agricolae/agricolae.pdf.

MIRANDA, E.E. Brasil em relevo [online]. Campinas: Embrapa Monitoramento por Satélite, 2005 [viewed 1 Apr. 2014]. Available from: http://www.relevobr. cnpm.embrapa.br.

MIRANDA, L.E., ANDREWS, C.S. and KROGER, R. Connectedness of land use, nutrients, primary production, and fish assemblages in oxbow lakes. Aquatic Sciences, 2014, 76(1), 41-50. http://dx.doi. org/10.1007/s00027-013-0310-y.

NAIMAN, R.J. and DÉCAMPS, H. The ecology of interfaces: riparian zones. Annual Review of Ecology 
and Systematics, 1997, 28(1), 621-658. http://dx.doi. org/10.1146/annurev.ecolsys.28.1.621.

OKSANEN, J., BLANCHET, F.G., KINDT, R., LEGENDRE, P., MINCHIN, P.R., O'HARA, R.B., SIMPSON, G.L., SOLYMOS, P., STEVENS, M.H.H. and WAGNER, H. Vegan: community ecology package. $R$ package version 2.0-6 [online]. CRAN, 2013 [viewed 10 Nov. 2014]. Available from: http://CRAN.R-project.org/package=vegan.

R CORE DEVELOPMENT TEAM. $R$ : A language and environment for statistical computing [online]. Vienna: R Foundation for Statistical Computing, 2015 [viewed 1 Feb. 2015]. Available from: http:// www.R-project.org/.

SCHEFFER, M., RINALDI, S., GRAGNANI, A., MUR, L.R. and VAN NES, E.H. On the dominance of filamentous cyanobacteria in shallow turbid lakes. Ecology, 1997, 78(1), 272-282. http://dx.doi. org/10.1890/0012-9658(1997)078[0272:OTDOF C]2.0.CO;2.
SILVA, E.I.L., SHIMIZU, A. and MATSUNAMI, H. Salt pollution in a Japanese stream and its effects on water chemistry and epilithic algal chlorophyll-a. Hydrobiologia, 2000, 437, 139-148.

SWANSON, C.D. and BACHMANN, R.W. A model of algal exports in some Iowa streams. Ecology, 1976, 57(5), 1076-1080. http://dx.doi. org/10.2307/1941073.

URREA-CLOS, G., GARCÍA-BERTHOU, E. and SABATER, S. Factors explaining the patterns of benthic chlorophyll-a distribution in a large agricultural Iberian watershed (Guadiana river). Ecological Indicators, 2014, 36, 463-469. http:// dx.doi.org/10.1016/j.ecolind.2013.09.007.

WARD, J.V. Riverine landscapes: biodiversity patterns, disturbance regimes, and aquatic conservation. Biological Conservation, 1998, 83(3), 269-278. http:// dx.doi.org/10.1016/S0006-3207(97)00083-9.

Received: 06 July 2015 Accepted: 28 October 2015 